\title{
Performance of Assaf Lambs Fed Two Upgraded Agricultural Wastes
}

\author{
Jamal ABO OMAR* and Jihad ABDALLAH \\ Department of Animal Production, Faculty of Agriculture and Veterinary Medicine, \\ An Najah National University, Nablus, Palestine
}

('Corresponding author's e-mail: aboomar57@najah.edu)

Received: 18 June 2016, Revised: 11 January 2018, Accepted: 10 February 2018

\begin{abstract}
Effects of ensiled greenhouse wastes (GHW), alkali-treated GHW and almond hulls (AH) on growth performance were studied on 24 Assaf lambs. All lambs were males with an average weight of $36.2 \mathrm{~kg}(\mathrm{~S} . \mathrm{D} .=2.1 \mathrm{~kg})$ at the beginning of the experiment. Animals were randomly divided into 4 groups of 6 lambs each. Lambs in each group received individually corn-soybean meal (SBM) total mixed rations (TMR). Rations were incorporated with a fixed amount $(200 \mathrm{~g} / \mathrm{kg})$ of the treated raw ingredients: ensiled greenhouse wastes, alkali-treated GHW and ensiled AH. All rations were isonitrogenous and isocaloric. The growth experiment lasted $80 \mathrm{~d}$. Both chemical and biological treatments had significant effects on improving crude protein (CP) and fiber fractions. At termination of the experiment, lambs fed treated ingredients (i.e., ensiled GHW, alkali-treated GHW, ensiled $\mathrm{AH})$ had better $(\mathrm{P}<0.05)$ feed conversion ratios and consumed less $(\mathrm{P}<0.05)$ feed. Treated GHW and AH had no effect on average daily gain $(\mathrm{P}=0.14)$ and total gain $(\mathrm{P}=0.21)$. Cost of gain was significantly lower in lambs fed the treated ingredients.
\end{abstract}

Keywords: Assaf lambs, greenhouse wastes, almond hulls, nutritive value, performance

\section{Introduction}

The Middle East is characterized by dry land farming. Depending on regional rainfall, the availability of forages and cereal crops is highly seasonal. The importance of roughage as a feed resource is decreasing at the expense of cereals and agro-industrial by-products [1-6]. Food crops leave a variety of residues (straws) that are utilized for animal feeding. Poor quality roughage comprises the only part of the diet for ruminant animals in most Middle East countries for a considerable period of the year. Crop residues and agro-industrial byproducts can play an important role in the feeding of sheep and goats under different management systems. Such residues can supply a substantial part of the maintenance requirements of small ruminants in the Asian region [7,8].

Crop residues, particularly cereal straws and a few agro-industrial byproducts such as almond hulls $(\mathrm{AH})$, greenhouse wastes (GHW), olive cake, citrus pulp, sesame oil cake, bakery wastes, and fruit and vegetable wastes have gained in importance due to the increasing demand of livestock feeds and due to competitive prices resulting from the removal of feed subsidies. The need to make better use of local feeds (crop residues, agro-industrial byproducts) is considered to be a promising way to alleviate feed deficit.

Difficulty in using most of these byproducts as fresh material for over long periods is one of the constraints in their wider use. The low nutritive value and the imbalanced nutrient profile of these byproducts is another reason which limits their use as components of small ruminant diets. The objectives of this research were to upgrade GHW and AH through ensiling and alkali treatments and to investigate the performance of Assaf lambs fed with these 2 by-products. 


\section{Materials and methods}

\section{Preparation of raw ingredients}

$\mathrm{AH}$ and GHW were obtained from local farms located near to the experimental site. The 2 ingredients were treated with $\mathrm{NaOH}$ as described by Nefzaoui [9] and were ensiled as described by Hadjipanayiotou [10].

\section{Animals and experimental design}

Twenty-four weaned male Assaf lambs with an initial mean weight of $36.2 \mathrm{~kg}(\mathrm{SD}=2.1 \mathrm{~kg}) \mathrm{were}$ used in the experiment. The experiment was conducted at a private farm, Tulkarm City, Palestine, after the approval of the Animal Care and Use Committee. Lambs were then assigned randomly to 4 experimental fattening diets (6 lambs/treatment). Lambs in each treatment were fed individually (Table 1), and each lamb was considered as an experimental unit. Animals in treatment groups were fed cornSBM based rations. Fixed amounts $(200 \mathrm{~g} / \mathrm{kg})$ of $\mathrm{GHW}, \mathrm{AH}$ silages, and $\mathrm{NaOH}$ treated $\mathrm{GHW}$ were incorporated in the rations. Conventional rations were fed to lambs in group 1 (the control group); however, ensiled GHW, alkali-treated GHW, and ensiled AH were fed to lambs in groups 2 - 4, respectively, in a completely randomized design, for 80 days, the duration of a regular fattening operation practiced in Palestine (Table 1). Rations fed were formulated to meet NRC [11] standards, and all diets were formulated to be isonitrogenous and isoenergetic. Lambs were housed in individual pens $(1.5 \times 1.00$ $\mathrm{m}^{2}$ ) with constant illumination and fed the experimental diets twice daily at 0900 and $1700 \mathrm{~h}$. Feeds offered and refused were recorded daily. Animal pens were cleaned weekly. Lambs weights were recorded weekly before the $0900 \mathrm{~h}$ feedings. Ingredient compositions of the experimental diets are shown in Table 1.

Table 1 Ingredient and chemical composition of experimental feeds incorporated with treated GHW and $\mathrm{AH}$ fed to Assaf fattening lambs, g/kg DM.

\begin{tabular}{lrccc}
\hline & \multicolumn{3}{c}{ Dietary group $^{1}$} & \\
\cline { 2 - 4 } & Control & Ensiled GHW & Alkali-treated & Ensiled AH \\
\hline Concentrate $^{\text {a }}$ & 800 & 800 & 800 & 800 \\
Wheat straw & 200 & 0 & 0 & 0 \\
GHW & 0 & 200 & 0 & 0 \\
AH & 0 & 0 & 200 & 0 \\
Almond hulls silage & 0 & 0 & 0 & 200 \\
Chemical analysis: (DM basis) & & & & 850 \\
DM & 890 & 550 & 580 & 782 \\
OM & 825 & 482 & 511 & 189 \\
CP & 188 & 190 & 190 & 158 \\
ADF & 188 & 150 & 160 & 518 \\
NDF & 540 & 520 & 490 & 650 \\
EE & 640 & 631 & 620 & 68 \\
Ash & 65 & 68 & 69 & 0.1 \\
Ca & 0.9 & 0.10 & 0.11 & 0.5 \\
Phosphorus & 0.5 & 0.6 & 0.6 & 1.57 \\
ME ${ }^{\mathrm{b}}$, MCal/ Kg DM & 1.60 & 1.57 & 1.60 & 0.48 \\
Cost of 1 kg diet, US\$ & 0.51 & 0.48 & 0.46 & \\
\hline
\end{tabular}

1 dietary group: control; ensiled green house waste (GHW); alkali treated; ensiled almond hulls (AH).

${ }^{a}$ Composition per $1 \mathrm{~kg}$ contained: yellow corn, $400 \mathrm{~g}$; soybean meal, $255 \mathrm{~g}$; wheat bran, $80 \mathrm{~g}$; ammonium chloride, 3 $\mathrm{g}$; dicalcium phosphate, $6 \mathrm{~g}$; NaCl, $3 \mathrm{~g}$; limestone, $17 \mathrm{~g}$; soapstock, $1 \mathrm{~g}$; premix, $1 \mathrm{~g}$ (composition per $1 \mathrm{~kg}$ : vitamin A, 2000000 IU; vitamin D3, 40000 IU; vitamin E, 400 IU; Mn, 12.8 mg; Zn, 9.0 mg; I, 1.56 mg; Fe, 6.42 mg; Co, 50 $\mathrm{mg}$; Se, $32 \mathrm{mg}$ plus antioxidant).

${ }^{b}$ Metabolizable energy: based on tabular values (NRC, 1985). 


\section{Chemical analysis}

Following AOAC [12] procedures, samples were analyzed for $\mathrm{DM}\left(100{ }^{\circ} \mathrm{C}\right.$ in an air-forced oven for $24 \mathrm{~h}$; method 967.03), ash $\left(550{ }^{\circ} \mathrm{C}\right.$ in an ashing furnace for $6 \mathrm{~h}$; method 942), and $\mathrm{CP}$ (Kjeldahl procedure, TECATOR, Box 70, Hoganas, Sweden). Additionally, samples were analyzed for neutral detergent fiber (aNDF; with heat stable-amylase and sodium sulfite) and acid detergent fiber (ADF; ANKOM2000 fiber analyzer, ANKOM Technology Corporation, Fairport, NY, USA) according to Soest et al. [13]. Values for aNDF and ADF were expressed inclusive of residual ash. The $\mathrm{pH}$ of silages was measured using a glass electrode $\mathrm{pH}$-meter according to Bolsen et al. [14]. The volatile fatty acids (VFA; acetate, butyrate and lactate, respectively) were measured by HPLC according to Erwin et al. [15].

\section{Statistical analysis}

Data were subjected to ANOVA for a completely randomized design using the general linear procedure of SAS [16]. Differences among treatment means for significant dietary effect were detected using Duncan's Multiple Range test. Unless otherwise stated, significance was declared at $\mathrm{P}<0.05$.

\section{Results and discussion}

\section{Silage}

GHW silage (GHWS) and AH silage (AHS) had higher $(\mathrm{P}<0.05) \mathrm{CP}$ content compared to $\mathrm{CP}$ in raw ingredients (GHW and AH, Table 2). The ensiling process resulted in 1.05 and 0.84 increases in $\mathrm{CP}$ in AHS and GHWS, respectively. The GHWS and AHS had a lower $(\mathrm{P}<0.05)$ NDF fraction compared to raw ingredients (Table 2). However, ensiling only decreased the ADF fraction in AH. The ensiling process decreased the NDF fractions in GHWS and AHS by 0.38 and 0.82, respectively. However, the reductions in the ADF fractions were 0.16 and 0.50 for GHWS and AHS, respectively.

Table 2 Chemical analysis of crude, alkali-treated and ensiled almond hulls (AH) and greenhouse wastes (GHW) fed to Assaf lambs.

\begin{tabular}{lcccccc}
\hline & DM $^{\mathbf{1}}$ & OM & CP & NDF & ADF & Ash \\
\hline AH & & & & & & \\
Crude & $89.0^{\mathrm{a}, 2}$ & $82.1^{\mathrm{a}}$ & $3.4^{\mathrm{b}}$ & $83.0^{\mathrm{a}}$ & $66.0^{\mathrm{a}}$ & $6.9^{\mathrm{a}, \mathrm{b}}$ \\
Alkali-treated & $82.3^{\mathrm{b}}$ & $74.7^{\mathrm{b}}$ & $5.5^{\mathrm{a}, \mathrm{b}}$ & $34.0^{\mathrm{c}}$ & $51.3^{\mathrm{a}}$ & $7.6^{\mathrm{a}, \mathrm{b}}$ \\
Ensiled GHW & $52.7^{\mathrm{d}, \mathrm{e}}$ & $44.5^{\mathrm{de}}$ & $7.1^{\mathrm{a}}$ & $15.3^{\mathrm{e}}$ & $32.7^{\mathrm{b}}$ & $8.2^{\mathrm{a}}$ \\
Crude & $53.3^{\mathrm{d}}$ & $46.1^{\mathrm{d}}$ & $3.3^{\mathrm{b}}$ & $24.0^{\mathrm{d}}$ & $20.3^{\mathrm{b}}$ & $7.2^{\mathrm{a}, \mathrm{b}}$ \\
Alkali treated & $72.3^{\mathrm{c}}$ & $65.9^{\mathrm{c}}$ & $4.1^{\mathrm{a}, \mathrm{b}}$ & $18.3^{\mathrm{c}}$ & $19.3^{\mathrm{b}}$ & $6.4^{\mathrm{b}, \mathrm{c}}$ \\
Ensiled & $48.7^{\mathrm{e}}$ & $43.4^{\mathrm{e}}$ & $6.9^{\mathrm{a}}$ & $15.0^{\mathrm{b}}$ & $17.0^{\mathrm{b}}$ & $5.3^{\mathrm{c}}$ \\
\hline
\end{tabular}

${ }^{1} \mathrm{DM}=$ dry matter, $\mathrm{OM}=$ organic matter, $\mathrm{CP}=$ crude protein, $\mathrm{NDF}=$ neutral detergent fiber, $\mathrm{ADF}=\mathrm{acid}$ detergent fiber, $\mathrm{EE}=$ ether extract.

${ }^{2}$ Means in the same column with different superscripts are significantly different $(\mathrm{P} \leq 0.05)$ using Duncan's Multiple Range test for multiple comparisons.

\section{Alkali treatment}

The sodium hydroxide treatment increased the CP of GHW and AH by 0.24 and 0.61 , respectively. This treatment resulted in about 0.24 and 0.59 decreases in the NDF contents of the treated GHW and $\mathrm{AH}$, respectively. The ADF values of the treated GHW and $\mathrm{AH}$ were reduced by 0.05 and 0.22 , respectively. 
http://wjst.wu.ac.th

\section{Feeding trial}

Animals fed the treated ingredients consumed less $(\mathrm{P}<0.05)$ total feed compared to the control animals (Table 3). Weight gain was similar in all treatments. However, treated ingredients resulted in $0.02-0.09$ increases $(\mathrm{P}=0.148)$ in lamb weight gain (Table 3).

Similar trend was observed for the $\mathrm{ADG}$, where both chemical (i.e., $\mathrm{NaOH}$ treatment) and biological (ensiling) treatments had positive effects $(\mathrm{P}=0.140)$ on the ADG (Table 3). Treated ingredients increased $(\mathrm{P}<0.05)$ FCR by $0.08-0.11$.

The cost per kg gain is shown in Table 3. The highest $(\mathrm{P}<0.05)$ cost of gain was observed in lambs fed the control ration.

Table 3 Effects of ensiled greenhouse wastes (GHW), almond hulls (AH) and alkali-treated GHW on feed intake, body gain, and feed conversion ratios (FCR) of Assaf lambs.

\begin{tabular}{lccccc}
\hline & \multicolumn{2}{c}{ Dietary group $^{\mathbf{1}}$} & \multirow{2}{*}{ P value } \\
\cline { 2 - 5 } & Control & Ensiled GHW & Alkali-treated GHW & Ensiled AH & \\
\hline DMI, kg & $1.84^{\mathrm{a}}$ & $1.77^{\mathrm{b}}$ & $1.75^{\mathrm{b}}$ & $1.74^{\mathrm{b}}$ & 0.0002 \\
Initial body weight, kg & 36.0 & 33.4 & 37.4 & 37.9 & 0.097 \\
Final body weight & 53.6 & 53.2 & 56.5 & 56.2 & \\
Weight gain, kg & 17.9 & 19.5 & 19.1 & 18.3 & 0.148 \\
Average daily gain, g & 288.0 & 314.5 & 308.8 & 295.7 & 0.140 \\
FCR & $6.4^{\mathrm{a}}, 1$ & $5.7^{\mathrm{b}}$ & $5.7^{\mathrm{b}}$ & $5.9^{\mathrm{b}}$ & 0.009 \\
Cost of 1 kg gain, \$ & $3.26^{\mathrm{a}}$ & $2.73^{\mathrm{b}}$ & $2.71^{\mathrm{b}}$ & $2.83 \mathrm{~b}$ & 0.001 \\
\hline
\end{tabular}

${ }^{1}$ Means in the same row with different superscripts are significantly different $(\mathrm{P} \leq 0.05)$ using Duncan's Multiple Range test for multiple comparisons. FCR $=$ Feed conversion ratio.

\section{Chemical compositions}

Laboratory analyses of GHW showed comparable values to those associated with the raw ingredients [17]. The CP of AH measured in this study (34.0 g/ $\mathrm{kg} \mathrm{DM})$ was higher compared to values in some previous reports [18-23] but was consistent with Fadel's [24] reported values. Differences among studies may be related to species or genetic variation. The $\mathrm{CP}$ content of almond hulls usually varies in the range of 48.724 and $80.010 \mathrm{~g} / \mathrm{kg} \mathrm{DM}$.

Ensiling of $\mathrm{AH}$ and GHW improved the $\mathrm{CP}$ content of both ingredients. There are considerable changes in the nitrogenous fractions of forages during ensiling. Microbial proteases appear to be relatively active throughout a period of fermentation. Schaadt and Johnson [25] reported a loss of true protein in corn silage, presumably due to proteolysis during ensiling; however, the time and severity of proteolysis is not clear. Filya [26] reported increasing amounts of $\mathrm{NH}_{3}-\mathrm{N}$ in corn and sorghum silages through ensiling. Kleinschmit et al. [27] reported a steady increase in $\mathrm{NH}_{3}-\mathrm{N}$ in corn silage through ensiling without reaching a plateau. Newbold et al. [28] reported increasing amounts of degradable CP with time.

The decrease in fiber content reported in this study may be due to the partial hydrolysis of hemicelluloses and lignin, which could be related to acidic conditions as a result of organic acid development in silage materials and the prevalence of anaerobic bacteria. The lignin fraction might be reduced because of the microbial degradation of the bonds between lignin and carbohydrate polymers (cellulose, hemicelluloses, lignin). High degradation of carbohydrate polymers may be due to the prevalence of anaerobic conditions which were suitable for the development of some microorganisms having the ability to aid in the breakdown of these polymers' carbohydrate active enzymes. 


\section{Feeding trial}

The improvement in performance might be due to the presence of easily digestible cell walls in the tested materials, which had a positive effect on rumen microflora, and to the high degradability of ADF and NDF in the presence of limited lignin content. Ben-Ghedalia et al. [29] showed that there is some improvement in nutrient utilization from by-products due to its positive effect on rumen microflora activity. Moreover, it has been proposed that the highly digestible fibrous fraction of the treated GHW and AH may increase the number of bacteria in ruminal fluid.

The average daily gain (ADG) in lambs fed the 4 rations was 288.8, 314.5, 308.0, and $295.7 \mathrm{~g}$ for the control, ensiled GHW, alkali-treated GHW and ensiled AH, respectively. The highest gain was observed in lambs fed ensiled GHW, while the lowest gain was associated with the control lambs. The increase in gain was due to organic acid and lactic acid, which improve the dry matter digestibility. Addition of readily fermented carbohydrates increased the rate of fermentation by increasing organic acids, which resulted in a low $\mathrm{pH}$ value. The higher feed intake (FI) observed in the control lambs might be the reason for the low FCR in these lambs.

Similar findings were reported where the ensiling process had some improvement associated with increasing total tract digestibility through effects on the structural carbohydrates [30-33].

The highly digestible fibrous fractions like those in silages and the sodium hydroxide-treated ingredients used in this experiment may have enhanced the number of bacteria in ruminal fluid and may have created favorable conditions in the rumen of lambs for the enhancement of microbial activity. The results of this pattern of fermentation caused the production of acetic acid, which promoted fat syntheses and more gain [34]. However, the differences observed in daily gain among lambs in different experimental groups may be attributed to a different pattern of volatile fatty acid production.

In order to calculate the amount of savings that could be achieved by feeding the treated ingredients, the averages of total gain, the FCR, and the cost of $1 \mathrm{~kg}$ feed of the rations (i.e., $19.0 \mathrm{~kg}, 5.8$, and 0.47 , respectively) were considered.

Cost of gain was reduced through feeding ensiled ingredients. This can be explained by the significant differences in price per $\mathrm{kg}$ among the tested rations (Table 3). The reported figures from this experiment show the economic feasibility of feeding such type of ingredients and the savings that could be achieved.

\section{Conclusions}

It can be concluded that ensiled GHW and AH or alkali-treated GHW had positive effects on the conversion ratio (CR) of Assaf lambs. Treated GHW and $\mathrm{AH}$ can be incorporated into concentrate mixtures, as crude, ensiled, or alkali-treated, at inclusion levels of $200 \mathrm{~kg} / \mathrm{t}$, with no adverse effects. Adoption of this option provides the fattening industry with an inexpensive, nonconventional feed ingredient, and reduces the environmental pollution caused by waste disposal.

\section{Acknowledgment}

The authors are thankful to the Ministry of Higher Education for funding the study and to the An Najah National University administration for research project support.

\section{References}

[1] H Steinfeld, CD Haan and H Blackburn. Livestock-environment Interactions, Issues and Options. Report. FAO Rome, World Bank Washington, 1998, p. 56.

[2] JA Omar. Utilization of corrugated cardboard in fattening rations of Awassi lambs. Small Rumin. Res. 2001; 42, 169-72.

[3] JA Omar. Effects of feeding different levels of sesame oil cake on performance and digestibility of Awassi lambs. Small Rumin. Res. 2002; 46, 187-90.

[4] A Zaza. 2008, Effects of Feeding Citrus Pulp and Olive Cake Silage on Performance and Digestibility of Awassi Lambs. Master Thesis. An Najah National University, Nablus, Palestine. 
http://wjst.wu.ac.th

[5] A Hejazi and JA Omar. Effect of feeding sesame oil cake on performance, milk and cheese quality of Anglo-Nubian goats. Hebron Univ. Res. J. 2009; 4, 81-91.

[6] JA Omar, R Daya and A Ghaleb. Effects of different forms of olive cake on the performance and carcass quality of Awassi lambs. Anim. Feed Sci. Tech. 2012; 171, 167-72.

[7] AW Qureshi. Current Trends and Possibilities of Increasing Small Ruminant Production in the Near East. FAO Animal Production and Health Paper. No. 54, Rome, Italy, 1987, p. 21-2.

[8] MCN Jayasuriya. Potential for Better Utilization of Crop Residues and Agro-industrial by Products in Animal Feeding in the Indian Sub Continent. FAO Animal Production and Health Paper. No. 54, Rome, Italym 1985, p. 37-49.

[9] A Nefzaoui. 1985, Lignocellulosic Wastes Valorisation in Ruminant Feeding by Alkali Treatment. Application to Olive Cake. Ph.D. Thesis. Catholic University of Louvain, Louvain-la-Neuve, Belgium.

[10] M Hadjipanayiotou. Feeding ensiled crude olive cake to lactating Chios ewes, Damascus goats and Friesian cows. Livest. Prod. Sci. 1999; 59, 61-6.

[11] National Research Council. Nutrient Requirements of Sheep. $6^{\text {th }}$ eds. Series Nutrient Requirements of Domestic Animals' National Academy of Press, Washington, DC. USA, 1985.

[12] Association of Official Analytical Chemists. Official Methods of Analysis of the AOAC., $12^{\text {th }}$ ed. Washington DC, USA, 1990.

[13] PJ Van Soest, JB Robertson and BA Lewis. Methods for dietary fiber, neutral detergent fiber, and nonstarch polysaccharides in relation to animal nutrition. J. Dairy Sci. 1991; 74, 3583-97.

[14] KK Bolsen, JT Dickerson, BE Brent, RNJ Sonon, BS Dalke, CJ Lin and JEJ Boyer. Rate and extent of top spoilage losses in horizontal silos. J. Dairy Sci. 1993; 76, 2940-62.

[15] ES Erwin, GL Marco and EM Emery. Volatile fatty acid analysis of blood and rumen fluids by gas chromatography. J. Dairy Sci. 1961; 44, 1768.

[16] SAS-Statistical Analysis System Institute. SAS/STATTM User's Guide: Statistics, Version 6. Vol. II, $4^{\text {th }}$ eds, Cary, NC, USA, 1989.

[17] O Tahseen, J Abdallah and JA Omar. In situ degradability of dry matter, crude protein, acid and neutral detergent fiber of olive cake and greenhouse wastes of tomato and cucumber. Revue Méd. Vét. 2014; 165, 93-8.

[18] T Yalchi and S Shahryar Kargar. Chemical composition and in situ ruminal degradability of dry matter and neutral detergent fiber from almond hulls. J. Food Agric. Environ. 2010; 8, 781-4.

[19] A Arosemena, EJ Depeters and JG Fadel. Extent of variability in nutrient composition within selected by-product feedstuffs. Anim. Feed Sci. Tech. 1995; 54, 103-20.

[20] EJ Depeters, JG Fadel And A Arosemena. Digestion kinetics of neutral detergent fiber and chemical composition within some selected by-products feedstuffs. Anim. Feed Sci. Tech. 1997; 67, 127-40.

[21] G Getachew, GM Grovetto, M Fondevila, U Krishnamoorthy, B Singh, M Spanghero, H Steingass, $\mathrm{PH}$ Robinson and MM Kailas. Laboratory variation of $24 \mathrm{~h}$ in vitro gas production and estimated metabolizable energy values of ruminant feeds. Anim. Feed Sci. Tech. 2002; 102, 169-80.

[22] G Getachew, PH Robinson, EJ DePeters and SJ Taylor. Relationship between chemical composition, dry matter degradation and in vitro gas production of several ruminant feeds. Anim. Feed Sci. Tech. 2004; 111, 57-71.

[23] National Research Council. Nutrient Requirements of Dairy Cattle. $7^{\text {th }}$ eds. National Academy of Sciences, Washington DC, USA, 2001.

[24] JG Fadel. Quantitative analyses of selected plant by-product feedstuffs, a global perspective. Anim. Feed Sci. Tech. 1999; 79, 225-68.

[25] HJ Schaadt and RR Johnson. Effect of ensiling time on distribution and losses of nitrogen in corn silage treated with limestone and NPN. J. Anim Sci. 1969; 29, 57-61.

[26] I Filya. The effect of Lactobacillus buchneri and Lactobacillus plantarum on the fermentation, aerobic stability, and ruminaldegradability of low dry matter corn and sorghum silages. J. Dairy Sci. $2003 ; 86,3575-81$. 
http://wjst.wu.ac.th

[27] DH Kleinschmit and LJ Kung. The effects of Lactobacillus buchneri 40788 and Pediococcus pentosaceus R1094 on the fermentation of corn silage. J. Dairy Sci. 2006; 89, 3999-4004.

[28] JR Newbold, EA Lewis, J Lavrijssen, HJ Brand, H Vedder and J Bakker. Effect of storage time on ruminal starch degradability in corn silage. J. Dairy Sci. 2006; 89, 190.

[29] D Ben-Ghedalia, J Yosef and Y Miron. The effect of starch and pectin-rich diets on quantitative aspects of digestion in sheep. Anim. Feed Sci. Tech. 1989; 24, 289-98.

[30] GD Urso, MC Sinatra, A Lanza and C Aleo. Conceivability and digestibility characteristics of ensiled citrus pulp and of ensiled mixture made up of citrus pulp and straw. Tech. Agric. 1984; 36, 5-15.

[31] G Licitra, V Chiofalo, M Avondo and GD Urso. Caratteristiche chimico-nutritive e di fermentazione degli insilati di carota, pastazzo di limone e paglia. In: Proceedings of the XLII National Congress S.I.S. Vet. Mantova, Italy, 1988, p. 1261-3.

[32] V Scerra, P Caparra, F Foti, M Lanza and A Priolo. Citrus pulp and wheat straw silage as an ingredient in lamb diets: Effects on growth and carcass and meat quality. Small Rumin. Res. 2001; 40, 51-6.

[33] P Caparra, CL Mammola, F Foti, V Sarullo, R Verdiglione and V Scerra. Citrus pulp fresh as an ingredient in lamb diets: Effects on carcass and meat quality. In: Proceedings of the $18^{\text {th }}$ International Congress of Mediterranean Federation for Health and Production of Ruminants. Giardini Axos, Italy, 2000, p. 272-5.

[34] M Volanis, P Zoiopoulos, E Panagou and C Tzerakis. Utilization of an ensiled citrus pulp mixture in the feeding of lactating dairy ewes. Small Rumin. Res. 2006; 64, 190-5. 